KAROLINA ĆWIEK-ROGALSKA

Instytut Slawistyki

Polskiej Akademii Nauk w Warszawie

\title{
O ZNACZENIACH BIBLIOTEKI W ADELHEID VLADIMÍRA KÖRNERA. STUDIUM PRZYPADKU
}

\author{
Słowa kluczowe: biblioteka, literatura czeska, wysiedlenia, Vladimír Körner, Adelheid
}

Keywords: library, Czech literature, displacements, Vladimír Körner, Adelheid

\section{Co można powiedzieć o bibliotece}

„Co można powiedzieć o bibliotece?”, zapytuje Umberto Eco w swoim klasycznym już dzisiaj tekście $O$ bibliotece, zapisie odczytu z 10 marca 1981 roku z okazji dwudziestopięciolecia Biblioteki Miejskiej w Mediolanie. I dodaje zaraz, rozwijając historię o przeznaczeniu bibliotek:

[...] potem powstały, jak mi się zdaje, biblioteki, które miały uniemożliwić czytanie, ukryć, chronić książki. Naturalnie te biblioteki miały także umożliwić odnajdywanie. Zawsze zadziwia nas, z jaką zręcznością piętnastowieczni humaniści odnajdywali zagubione manuskrypty. Gdzie je odnajdywali? W bibliotece. W bibliotekach, które służyły częściowo do ukrywania, ale również umożliwiały odnajdowanie ${ }^{1}$.

W bibliotece istniejącej realnie, w świecie pozatekstowym, można poszukiwać zaginionych rękopisów - można, co pokazuje przykład czeskiego działacza narodowego, archiwisty i bibliotekarza Václava Hanki, je tam także wytwarzać -w zawartości biblioteki opisanej zaś, istniejącej wyłącznie na kartach powieści, można doszukiwać się ukrytych znaczeń i rozwiązań nieprzedstawionych przez pisarza bezpośrednio. Właśnie tą drugą sytuacją chciałabym się zająć w niniejszym tekście.

\footnotetext{
${ }^{1}$ Umberto Eco, O bibliotece, trans. Adam Szymanowski (Warszawa: Świat Książki, 2007), 14.
} 


\section{Przestrzeń}

W 1967 roku, w karnawale Praskiej Wiosny, scenarzysta filmowy i pisarz Vladimír Körner publikuje jedną ze swoich najgłośniejszych książek, Adelheid. To historia relacji Czecha Viktora Chotovickiego i Niemki Adelheid Heidenmann, osadzona w realiach późnego lata, jesieni i zimy 1945 roku. Viktor właśnie wrócił zza granicy, wojnę spędził bowiem na Wyspach Brytyjskich w służbie pomocniczej RAF. Przez wzgląd na dawne znajomości został administratorem (czes. národní správce) wielopokojowej posiadłości ojca Adelheid, gdzie znajduje się imponująca biblioteka. Sama Adelheid, której ojciec był lokalnym nazistowskim prominentem, musi wyprowadzić się z domu i oczekuje na wysiedlenie w obozie przejściowym dla ludności niemieckiej, położonym poza wsią. Zostaje jednak przydzielona Viktorowi do pomocy - staje się służącą w niegdyś własnym mieszkaniu. Ponieważ Viktor, jak twierdzi, „zapomniał”, jak posługiwać się językiem niemieckim, a Adelheid nie mówi po czesku, kontakt werbalny między postaciami w powieści sprowadzony został do minimum. Zamiast tego Körner kazał postaciom porozumiewać się za pomocą odczytywania znaczeń przestrzeni, w których je osadził oraz obecnych w tychże przestrzeniach rzeczy.

Viktor i Adelheid spędzają czas przede wszystkim w stylizowanym na gotycki dworze Heidenmanna i to za pomoca charakterystyk jasno wydzielonych w powieści poszczególnych przestrzeni dochodzi do pozawerbalnej komunikacji między bohaterami. W ten sposób jednak możliwe jest nie tyle odczytanie tego, co myśli bądź czuje druga postać, ale zinterpretowanie jej zamiarów, historii i motywacji. Jak zauważała Anna Gawarecka „nie wszystko jednak [w literaturze poświęconej tematowi wysiedleń, tworzonej od lat sześćdziesiątych] można powiedzieć. Nie tylko ze względu na dyrektywy i zakazy cenzury, również, być może nawet, głównie ze względu na przymus respektowania przekonań zakorzenionych w świadomości zbiorowej" 2 . Odmiennie jednak od autorki powyższych słów - która wskazywała, że omijano to, stosując rozwiązania takie jak pokazywanie czytelnikowi nie zbiorowych schematów, ale konkretnych przypadków i eksponowania wieloznaczności sytuacji, w jakiej znajdują się bohaterowie - poszukuję innego rozwiązania. Uważam, że Körner pozostawił w Adelheid wskazówki pozwalające odczytywać z niej to, co nie zostaje powiedziane wprost - i że wkomponował je we fragmenty dotyczące biblioteki. Tym samym sama symbolika biblioteki w przywoływanej powieści staje się bogatsza i gęstsza: zachęca, by czytelnik oprócz tego, co explicite znajduje się w tekście, próbował

\footnotetext{
${ }^{2}$ Anna Gawarecka, „Dialog i milczenie w czeskiej prozie poświęconej tematyce wysiedlenia Niemców”, in Przemilczenia w relacjach międzykulturowych, eds. Joanna Goszczyńska, Grażyna Szwat-Gyłybowa (Warszawa: Slawistyczny Ośrodek Wydawniczy, 2008), 200.
} 
doszukiwać się rozwiązań schowanych implicite między książkami, które porządkują Viktor i Adelheid. Zgadzam się zatem z intuicjami Gawareckiej, piszącej że „puste miejsce po nieobecnych słowach wypełniają [bohaterom Adelheid] iluzje"3. Uważam jednak, że nie jest tak, jak chce literaturoznawczyni, że to „milczenie, nie dialog, stanowi dla pisarza rękojmię porozumienia” ${ }^{4}$, i że „dopóki owo milczenie trwa, nie znika również szansa na odbudowę pełnowartościowych związków interpersonalnych, gdzie zaczyna się rozmowa, szansa ta nabiera

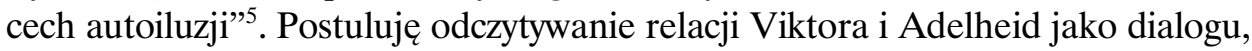
ale dialog ów odbywa się pomiędzy bohaterami nie w postaci wymiany zdań, ale interpretacji przedmiotów i zachowań wobec nich przejawianych, czy wreszcie przez stosunek do opisywanych przestrzeni. Tak też $\mathrm{w}$ tym artykule będę używała słowa „dialog”.

Autor od początku przeprowadza ten rodzaj komunikacji pomiędzy bohaterami, skazując ich na wikłanie się w wyobrażenia, nie pozwalając im poznawać faktów o sobie. Czyni to za pośrednictwem przestrzeni, odnajdywanych w nich przedmiotów oraz książek z biblioteki starego Heidenmanna. Anna Gawarecka dostrzega znaczenie rzeczy, gdy w zakończeniu swojego studium o Adelheid pisze: „Gdy brakuje ludzi, funkcje interlokutora w dialogu przejmuje właśnie ów palimpsest, złożony z pozostałości kultury duchowej i materialnej”6. Przyjmując to jako punkt wyjścia do dalszych badań nad powieścią pragnę zaprezentować jej odczytanie właśnie przez pryzmat biblioteki.

Dlaczego tak ważna jest rola tej właśnie przestrzeni w powieści? Jak pisze Michał Kaczmarek, opracowując znaczenie biblioteki w studiach pamięcioznawczych: „zestawienie pojęć biblioteka i pamięć pokazuje pewne podobieństwo funkcji, praktyk i działań. Gromadzenie jest równocześnie zapamiętywaniem, opracowywaniem i przechowywaniem, katalogowanie - formą porządkowania, udostępnianie - przypominaniem, a selekcjonowanie wiąże się z zapominaniem"7. W powieści Körnera, w której przedstawia on świat po spełnionej Apokalipsie, gdzie kończy się wielowiekowe współżycie Czechów i Niemców, dochodzi do takiej właśnie selekcji treści: zapadają decyzje o tym, co zapamiętać, a co zapomnieć, żeby móc dalej funkcjonować. Staje się to udziałem dwójki głównych bohaterów, dla których katalogowanie zbiorów Heidenmanna może być rękojmią porozumienia - w celu budowania wspólnej przeszłości, opartej na pewnym wyborze materiału do zapamiętania i do zapomnienia - lub konfliktu, opartego na wzajemnym niezrozumieniu. Biblioteka staje się tutaj

${ }^{3}$ Ibidem, 203.

${ }^{4}$ Ibidem.

${ }^{5}$ Ibidem, 203-204.

${ }^{6}$ Ibidem, 210.

${ }^{7}$ Michał Kaczmarek, „Biblioteka”, in Modi memorandi. Leksykon kultury pamięci, eds. Magdalena Saryusz-Wolska, Robert Traba (Warszawa: Scholar, 2014), 60. 
„zmaterializowaną i uporządkowaną pamięcią", która w procesie budowania i zanikania relacji między bohaterami wskazuje nie tylko na to, co dzieje się między nimi, ale także na autorską prognozę stosunków czesko-niemieckich czy nawet sąd o przemianach roku 1968.

Moim zdaniem można zatem nie tylko odczytywać Adelheid jako rodzaj przewrotnej love story między bohaterami pochodzącymi z dwóch różnych (narodowościowo i klasowo) światów - tak jak często odczytywana jest do dzisiaj ${ }^{9}$, a co umocnił dodatkowo nakręcony wkrótce po powstaniu książki słynny film Františka Vláčila na podstawie scenariusza samego Körnera, ale również jako bardziej ogólną przypowieść o losach relacji czesko-niemieckich po roku 1945. $\mathrm{W}$ ten sposób przestrzenie znaczące $\mathrm{w}$ utworze nie służą wyłącznie wewnątrztekstowej komunikacji między postaciami, ale również komunikowaniu się autora z czytelnikiem, co dzieje się za pomocą zastawianych przez Körnera pułapek i zadawanych zagadek ${ }^{10}$. W artykule poświęconym przestrzeni w Adelheid Petr Bubeníček zauważa, że „przestrzeń w dziele Körnera jest otwartą strukturą znaczenia i wielkim wabikiem dla czytelnika i dla filmowca"11. Konstrukcja przestrzeni zmusza bohaterów do nieustannej konfrontacji z tym, co ich otacza. Stanowi kontrapunkt dla ich działań lub staje się nośnikiem sensów, których czasami oni sami nie są w stanie rozszyfrować. Sensy te pozostają zatem do odczytania dla czytelnika. W ten sposób biblioteka może się w tekście Adelheid stać owym miejscem służącym „częściowo do ukrywania”, jak chce Eco, „ale również umożliwia[jącym] odnajdowanie”.

\section{Zawartość biblioteki}

Do obowiązków Viktora jako administratora posiadłości należy skatalogowanie majątku, który się w niej jeszcze znajduje. Przybywając na miejsce odkrywa on, że część została już splądrowana, ale jednym z mniej poszkodowanych przez szaber miejsc w domu jest biblioteka. Właśnie nią zajmuje się więc w pierwszej

${ }^{8}$ Ibidem, 60 .

${ }^{9}$ Cf. Anna Gawarecka, op. cit.; Aleš Haman, „Existence ve zhrouceném světě. Postavy sudetských Němců v prózách Jaroslava Durycha, Vladimíra Körnera a Václava Vokolka”, in Odsun - Transfer - Vyhnání, eds. Gertraude Zand, Jiří Holý (Brno: Host, 2004), 98-105; Václav Maidl, „Obraz německy mluvících postav a německého prostředí v české literatuře 19. a 20. století”, in Obraz Němců, Rakouska a Německa v české společnosti 19. a 20. století, eds. Jan Křen, Stanislav Biman, Eva Broklová (Praha: Karolinum, 1998), 281-302; Drahomíra Vlašinová, Baladické prózy z přelomu času. Nad tvorbou Vladimíra Körnera a Věry Sladkové, „Česká literatura”, no. 4 (1985): 289-297.

${ }^{10}$ Jak zauważa Václav Maidl, odmienność prozy Körnera na tle innych powieści poświęconych relacjom czesko-niemieckim leży również w ograniczeniu przestrzeni, w jakiej się rozgrywa, i w sensach, które w tę przestrzeń zostają wpisane. Václav Maidl, op. cit., 296, 299.

${ }^{11}$ Petr Bubeniček, Krajina v literatuře a ve filmu: $k$ proměnám narativního prostoru, „Musicologica Brunensia", no. 46 (2011): 39. 
kolejności. Czyni tak nie tylko ze względu na nałożone na niego obowiązki, ale także z własnej woli, by zrealizować swoje marzenia: książki fascynowały go od dawna. Wspomina: „kdysi si přál mít tolik knih, aby mohl neustále číst, celé dny číst o životě a třeba ten svůj vůbec nežít"12. Problem polega jednak na tym, że posługuje się językiem czeskim i, jak możemy domniemywać, angielskim - odżegnuje się zaś od znajomości niemieckiego, a nie rozumie również ani łaciny, ani greki, w których to językach została napisana większość zgromadzonych w bibliotece książek. Już na samym początku mamy zatem do czynienia z sytuacją paradoksalną: bohater znajduje się w miejscu, o którym przez wiele lat marzył, okazuje się ono jednak dla niego niedostępne w treści, a obecne jedynie w formie. Viktor może zatem katalogować książki, ale marzeń o czytaniu nie dane mu będzie w pełni realizować. Jego kontakt ze zgromadzoną przez Heidenmanna literaturą odbywa się zatem - podobnie jak kontakt z jego córką - poza słowami, realizuje się w fizycznym dotknięciu.

Księgozbiór Heidenmanna robi na bohaterze niepokojące wrażenie. Pierwszy jego powód to wspomniana niezrozumiałość języków, w jakich napisane są zgromadzone tu książki, a drugi - że niektóre z nich to dzieła o wybitnie narodowosocjalistycznym charakterze, których musi się pozbyć. Prowadzenie ewidencji książek to zatem nie tylko skreślanie starych numerów i nadawanie im nowych, to również dokonywanie czystki - wymazywanie tych elementów, które doprowadziły do zagłady kwitnącej tu od wieków kultury niemieckojęzycznej. Symbolem tego przedsięwzięcia może być dziwna ozdoba pomieszczenia - wiszący na ścianie miecz, który jakby zwiastował zagładę swojemu panu i jego książkom.

Viktor wzdraga się jednak przed paleniem książek. Kiedy odwiedza go miejscowy sierżant wraz z członkiem tzw. gwardii rewolucyjnych, okrytych złą sławą ochotniczych jednostek zbrojnych mających pacyfikować nastroje na pograniczu, Viktor akurat kończy porządki. Tymi, którym przyjdzie pozbyć się zbiorów Heidenmanna, są jego goście. On sam zaznacza, że nie będzie ich palit ${ }^{13}$. W świetle płomieni buchających z oblanych alkoholem książek odbywa się dekadencka uczta na ruinach ginącego świata niemieckojęzycznej kultury, w której uczestniczą trzej przedstawiciele nowego ładu - z których jeden, Viktor, nie rozumie i nie potrafi zrozumieć, czego reprezentantem ma się stać ${ }^{14}$. To właśnie wtedy padają znamienne słowa o tym, że „tam venku není nic - stejně jako tady.

${ }^{12}$ Vladimír Körner, Adelheid (Praha: Československý spisovatel, 1967), 27. „Kiedyś życzył sobie mieć tyle książek, żeby móc bez przerwy czytać, całymi dniami czytać o życiu i na przykład tego swojego w ogóle nie przeżywać”. Wszystkie cytaty z Adelheid - w thumaczeniu autorki artykułu.

${ }^{13}$ Ibidem, 44. Jeśli za kontekst dla tego działania uznać proceder opisany przez Bohumila Hrabala w Zbyt głośnej samotności - wysyłanie książek na przemiał - to działania Viktora można uznać za absurdalne.

${ }^{14}$ Palenie książek można odczytywać jako metaforę zapominania. Michał Kaczmarek, Biblioteka, 61 . 
Smilstvo, zlodějny, samé kurvy a nenormalní ženy"15. Widoczne jest jednak, że Viktor nie pojmuje mechanizmów działania świata po wojnie, który jest już światem po spełnionej Apokalipsie. Sądzi, że Czechosłowacja, czy pogranicze, jest przestrzenią funkcjonującą na zasadach podobnych do tych, jakie poznał na Zachodzie. Nie zauważa, że podziały polityczne, które znał, już nie istnieją, a cała sytuacja społeczno-gospodarcza nie ma nic wspólnego z minioną przedwojenną Pierwszą Republiką Czechosłowacką. Z tych powodów możemy mówić o obojętności Viktora w stosunku do polityki - bohater nie rozumie i nie chce zrozumieć swojej sytuacji, wybierając neutralność.

Biblioteka staje się miejscem, gdzie poszukuje takiej neutralności: przestrzenią, w której zgromadzony jest dorobek kulturalny, po usunięciu dzieł nazistowskich mający zdaniem Viktora również neutralny, ponadnarodowy charakter. Tam więc skieruje się po pierwszej wspólnie spędzonej nocy z Adelheid. Viktor nie wie, co ma powiedzieć dziewczynie, wszystkie słowa wydają mu się niezręczne. Do stosunku seksualnego między nimi dochodzi zresztą pod wpływem zdania, które bohater długo wcześniej przygotowywał ze słownikiem. W końcu siadają więc razem w bibliotece, żeby kończyć wprowadzanie nowej ewidencji do księgozbioru Heidenmanna i pierwszymi słowami, jakie padają między nimi są: Leibniz, Octavia, Hölderlin, Die Vollendung der Natur. Dwa to nazwiska autorów (Leibniz, Hölderlin), dwa to tytuły dzieł (Octavia, Die Vollendung der Natur). Posiadają one charakter kolejnej zagadki, przygotowanej przez autora dla czytelnika. Nie jest to bowiem przypadkowe zestawienie tytułów i autorów, a treści, które kryją się pod nimi - nieanalizowane przez bohaterów, bo na dalszy plan odsuwa je znalezienie pamiętnika Adelheid - są możliwe do odczytania.

Na początku sceny pada nazwisko Gottfrieda Wilhelma Leibniza. Przywołanie nazwiska twórcy teorii teodycei, wyrażającego przeświadczenie, że żyjemy w „najlepszym z możliwych światów”, zdaje się być ironicznym komentarzem do sytuacji, w której znaleźli się bohaterowie (chodzi zarówno o jej całościowy wymiar, jak i o moment, w którym znajduje się relacja Viktora i Adelheid). Biblioteka jako ledwo ocalałe ruiny dawnej kultury - z sugestią w narracji, że mogą nie ocaleć podobnie jak to, co już spłonęło dzięki nowym władzom reprezentowanym przez sierżanta i młodego gwardzistę - staje się zatem świadkiem przywołania teorii upewniającej, że nie mogło być inaczej niż się stało. Wskazuje to na przenikający całą powieść duch pesymizmu, widoczny również w innych dziełach Körnera, przeświadczenia o nieuchronności ludzkiego losu i o niemożliwości pogodzenia Czechów i Niemców. Rozwiązanie, jakie przedstawia autor, $\mathrm{w}$ tak potraktowanym świecie przedstawionym jest więc jedynym możliwym.

${ }^{15}$ „Vladimír Körner, Adelheid, 48. „Tam na zewnątrz nie ma nic - tak samo jak tutaj. Ruja, złodziejstwo, same kurwy i wariatki”. 
Ten pesymistyczny ton pogłębia pojawienie się nazwiska Friedricha Hölderlina. Ten wielki niemiecki twórca w swoim wierszu Powołanie poety pisał, że to poeta właśnie jest tym, który pieśnią zbliża ludzi do bogów i bogów do ludzi. To z jego „zaprzyjaźnionej piersi” płynie pieśń wciąż na nowo opiewająca bogów. Służbie poetów należy powierzyć coś więcej niż zwykły trud człowieka, są oni łącznikami między ziemią i niebem. Co zatem dzieje się, kiedy pieśń milknie, kiedy nie może - z racji nieznajomości języka - zostać odczytana i zrozumiana? Człowiek zostaje pozostawiony sam sobie, bogowie odsuwają się i milczą, bo nie ma pieśni, w której mogliby przemówić do ludzi. Podkreśla to jeszcze sytuacja, w której pada wyłącznie nazwisko autora, nie zostaje zaś odczytany nawet drobny urywek z jego twórczości. Körner jest tutaj bezwzględny: nie ma miejsca na werbalny dialog, który zbliżałby do metafizycznych sensów. Pozostają odczytania tego, co materialne (okładki książek, ich numery w katalogu, które Viktor przekreśla), kontakt cielesny między Viktorem a Adelheid. Po raz kolejny zostaje podkreślone ${ }^{16}$, że książki otaczające bohatera nie mogą być odczytane i są skazane na to, by ich treść była zapomniana.

Przechodząc do interpretacji dwóch tytułów, które padają w tej scenie, chciałabym podkreślić, że wybrałam tu możliwości najbardziej prawdopodobne. Körner nie pozostawia bowiem większej ilości wskazówek nad to, co zostało powiedziane wcześniej: dzieła te należy identyfikować wśród klasycznej, łacińskiej, i niemieckiej literatury. Octavia zatem może być tytułem dramatu przypisywanego Senece (autorstwo nie jest pewne), opowiadającym o losie córki cesarza Klaudiusza, wygnanej z Rzymu przez Nerona z obawy przed konkurencją do tronu. Budzi to skojarzenia z planami władz czechosłowackich, chcących pozbyć się Niemców w obawie przed powtórzeniem się sytuacji z 1938 roku, a także z losem Adelheid, córki lokalnego prominenta, która już jest pozbawiona majątku, a dodatkowo ma opuścić kraj, by nie móc się o tenże majątek upominać. Adelheid - imię znaczące, bo odwołujące się chociażby do postaci złej władczyni w Götzu von Berlichingen Johanna Wolfganga von Goethego - jest tutaj reprezentantką dotychczasowych władców, którzy muszą zniknąć. To, że nowi panowie tych przestrzeni nie mają na nie pomysłu i przeważnie je niszczą, podkreśla porównanie do Nerona, cesarza, który spalił Rzym. Wielojęzyczne pogranicze również na oczach bohaterów przestaje istnieć - warto tutaj jeszcze raz przywołać też scenę ogniska-pożaru, w której płonie część bibliotecznych zbiorów.

${ }^{16} \mathrm{~W}$ swojej analizie motywów znajdujących się we wczesnych prozach Körnera Blahoslav Dokoupil wskazuje na powracające wciąż motywy i ich rolę, dzieląc je na antycypujące akcję, upamiętniające, charakteryzujące, przestrzenne i symboliczne. W niniejszym odczytaniu roli biblioteki w powieści motyw wzajemnej nieznajomości swoich języków można uznać za charakteryzujący bohaterów, jak również za motyw przestrzenny. Cf. Blahoslav Dokoupil, „Motivická výstavba prvních próz Vladimíra Körnera”, in Zlatá šedesátá. Česká literatura, kultura a společnost v letech tání, kolotání a... zklamání, ed. Radka Denemarková (Praha: Ústav pro českou literaturu, 2000), 165-172. 
Die Vollendung der Natur to z kolei tytuł pracy protestanckiego teologa Karla Bornhäusera, a jednocześnie idea żywo obecna zarówno w niemieckiej myśli protestanckiej, jak i u filozofów klasycznego niemieckiego idealizmu oraz następców nawiązujących do ich spuścizny. „Dopełnienie się natury” można rozumieć dwojako: albo jako dopełnienie męki Chrystusa w sakramentach Kościoła albo jako ideę koniecznego dziejowego procesu doskonalenia się natury czy samopoznania Absolutu (dla przykładu: u Friedricha Nietzschego zwieńczeniem rozwoju natury jest nadczłowiek). Da się to na dwa sposoby odnieść do momentu historycznego, w którym rozgrywa się akcja Adelheid. Może to być albo ironiczny komentarz do nazistowskich świetlanych planów udoskonalenia świata, albo przewrotne uznanie nadchodzącego wysiedlenia za voll-endung: wy-pełnienie się, $s$-pełnienie się, do-pełnienie się (czesko-niemieckiej) historii. Do takiej interpretacji skłaniają również tuż powojenne deklaracje władz czechosłowackich, że dopiero przez wysiedlenie ludności niemieckojęzycznej skończy się proces czeskiego odrodzenia narodowego, zapoczątkowanego odróżnieniem się Czechów od Niemców i postępującą dyferencjacją obu nacji.

Chociaż wielokrotnie przywołany został przeze mnie powtarzający się w Adelheid motyw nieznajomości języka niemieckiego przez bohatera, należy jeszcze zwrócić uwagę na to, że pierwszą książką w bibliotece Heidenmanna, którą znajduje Viktor, jest otwarty na pulpicie do czytania utwór Walthera von der Vogelweidego. Bohater twierdzi, że nie zna niemieckiego - a jednak wydobywa z pamięci fragmenty wiersza, poznanego jeszcze w szkole. Ta praca pamięci, którą wykonuje tutaj Viktor, jest dwuznaczna: pozwala ominać deklarowaną nieznajomość niemczyzny, a równocześnie odsyła do wcześniejszego kontekstu politycznego, do Pierwszej Republiki Czechosłowackiej, kiedy Viktor jako uczeń poznawał niemiecki w szkole. To, że taka anamneza jest w ogóle możliwa, ponownie uzmysławia, w jak niewielkim stopniu bohater rozumie otaczającą go rzeczywistość, wrogą wszak wszystkiemu, co niemieckie - nawet we wspomnieniach.

Dwa przypomniane sobie przez bohatera wiersze stanowią początki dwóch zaangażowanych politycznie pieśni, napisanych przez Vogelweidego między 1198 a 1201 rokiem. Obie te pieśni wyróżnia specyficzna melodyka strof, określana jako Reichston ${ }^{17}$. Początek pierwszej pieśni w tłumaczeniu na nowoniemiecki brzmi: „Ich sass auf einem Steine / und deckte Bein mit Beine”18. Początek drugiej zaś: „Ich hört' die Wasser düsseln / und sah die Fische fliessen”" ${ }^{19}$. Bohater analizując ten fragment zauważa, że wszystko, co kiedykolwiek widział, miało wymiar jedynie materialny, nie zaś duchowy - a do tych wartości odnosi się przecież cała poezja niemieckojęzycznego poety.

${ }^{17}$ Cf. Marian Szyrocki, Dzieje literatury niemieckiej (Warszawa: Państwowe Wydawnictwo Naukowe, 1969), 86.

18 „Siadłem na kamieniu / i założyłem nogę na nogę”.

19 „Słyszałem, jak szumi woda / i widziałem, jak pływają ryby”. 
Wiersz Vogelweidego mówi bowiem o poszukiwaniu kompromisu pomiędzy posiadaniem zaszczytów ziemskich i majątku a łaską Bożą, ale poeta dochodzi do wniosku, że nie można zamknąć tej trójki w „,jednej skrzyneczce” - los starego Heidenmanna może tu być dowodem, że poeta miał rację. Jednocześnie i Viktor uważa, że wiersz dotyczy jego własnych losów, bowiem: „খšechno, co jsem kdy spatřil, bylo jen na tomto světě" ${ }^{20}$. W samych wierszach, pomimo refleksyjnego charakteru początku pieśni pierwszej i sielskiego obrazu, pojawiającego się na początku pieśni drugiej, przeważa nastrój niepokoju o sytuację w Niemczech w okresie bezkrólewia u początku XIII wieku. Dodatkowego znaczenia nabiera zatem to, że Viktor odnajduje te strofy w 1945 roku, w czasie swoistego interregnum. Nie wiadomo bowiem nadal, kto właściwie obejmie władzę nad czeskim pograniczem, w Czechosłowacji toczy się rozgrywka między komunistami i przedstawicielami przedwojennego rządu z prezydentem Edvardem Benešem na czele, sytuacji nie poprawia także to, że w okolicy wciąż grasują niedobitki niemieckich żołnierzy. Viktor przebywa na terenie, który od siedmiuset lat kształtował się pod wpływem nie tylko kultury czeskiej, ale również niemieckiej. Przywołanie akurat Vogelweidego może tu zostać zatem odczytane jako znak przynależności tych terenów do ziem Cesarstwa Niemieckiego, w związku z którym pozostawały, a którego pozostałości definitywnie rozpadają się na skutek konferencji pokojowych w Teheranie, Jałcie i Poczdamie. Podzielone, okrojone w swoich granicach Niemcy nie są w tym czasie istotnym graczem na arenie międzynarodowej, nie mogą też rościć sobie pretensji do wielkiej przeszłości.

Można jednak interpretację tę jeszcze pogłębić. W czasie bowiem, kiedy powstały rzeczone poezje Vogelweidego, trwał konflikt Filipa Szwabskiego z Ottonem IV Welfem - sympatia polityczna poety była po stronie tego pierwszego. Co więcej Vogelweide wyrażał wyraźny sprzeciw wobec interwencji z zewnątrz (w tym wypadku: ze strony papieża), mającej wesprzeć starania Ottona o tron. Można doszukiwać się w tym analogii między sytuacją Vogelweidego a sytuacją autora Adelheid - powieść opublikowano bowiem, jak wspominałam, w czasie politycznej odwilży lat sześćdziesiątych, będącej także czasem intensywnego poszukiwania nowego modelu ustrojowego w Czechosłowacji, jakim miał być „socjalizm z ludzką twarzą” i płomiennych dyskusji na ten temat wśród ówczesnych intelektualistów i artystów. Świadomie przeprowadzam tu analogię pomiędzy autorami dzieł, a nie pomiędzy podmiotem lirycznym pieśni a Viktorem. Znaleziony tomik, otwarty właśnie na tych pieśniach, jest elementem sytuacji zastanej, niewykreowanej przez bohatera. Został zatem zaprojektowany przez autora $\mathrm{w}$ konstrukcji świata przedstawionego. $\mathrm{Z}$ o wiele większym

${ }^{20}$ „Wszystko, co kiedykolwiek widziałem, istniało tylko na tym świecie”. Vladimír Körner, Adelheid, 28. 
prawdopodobieństwem można tu więc mówić o autorskiej intencji niż o niebezpośrednim elemencie charakterystyki głównego bohatera. Viktor pozostaje do końca postacią politycznie indyferentną.

\section{Rozwiązywanie zagadek}

Jak zostało wspomniane, w rozległej, mieszczącej wiele woluminów bibliotece starego Heidenmanna oprócz książek Viktor znajduje także pamiętnik Adelheid. Służy on Viktorowi jako narzędzie do odczytania historii dziewczyny i interpretacji jej zachowania. Śledząc kolejne zapiski, bohater zauważa, że: „od prvních poupat a říkanek pro mladé děvče přibývalo v památníku kř́ižů a strohých goticky uzpůsobených písmen" ${ }^{21}$. Z jednej strony zatem nasuwa się tutaj interpretacja spójna $\mathrm{z}$ dojrzewaniem nastrojów radykalnych i nacjonalistycznych wśród czeskich Niemców od początku lat trzydziestych XX wieku, która znajduje odbicie w śladach dojrzewania samej dziewczyny. Im starsza się staje, tym więcej miejsca w pamiętniku znajduje nie płocha rozrywka o charakterze uniwersalnym, ale ślady fascynacji ideologią wielkoniemiecką i volkistowską - lub może po prostu odbicie tego, co działo się i o czym mówiło w jej otoczeniu. Tak też zachowanie i postawę Adelheid odczytuje Drahomíra Vlašínová22.

Sprawa jednak wcale nie jest taka prosta: na końcu książeczki znajduje się wpis w języku czeskim. Jeśli faktycznie Adelheid dojrzewała w cieniu nazizmu i do jej głowy przesączały się zatrute idee narodowego socjalizmu, to dlaczego miałaby prosić jakiegoś Czecha o wpis do pamiętnika? Jest to zresztą bardzo znaczący wiersz: „Boží slunce, které jde samotné ve slepotě nadcházejícího času, jde $\mathrm{k}$ rozcestí v poli, kde se rozejdeme, tam stojí kříž" ${ }^{23}$. Wiersz ten, wpisany do pamiętnika jesienią tuż przed wojną, wygląda jak zapowiedź późniejszych losów tych ziem. Tak samo miały się przecież rozejść drogi Czechów i Niemców, którzy gdzieś poza wsią stłoczeni w obozie oczekiwali na wysiedlenie. Ślady dotyczące przeszłości Adelheid są więc niejednoznaczne, podobnie jak więcej niż jedną interpretację posiada większość obecnych w bibliotece, a przywołanych powyżej, dzieł.

Warto zauważyć, że każdą z opisanych przeze mnie w tym artykule zagadek da się rozszyfrować na dwóch poziomach: prywatnym (odnoszącym się do sytuacji bohaterów) i publicznym (dotyczącym relacji czesko-niemieckich w ogóle). Biblioteka w dworze Heidenmanna skrywa niechlubne ślady przeszłości bohaterów

${ }^{21}$ „Od pierwszych pączków i rymowanek dla młodych dziewcząt przybywało w pamiętniku krzyżów i srogich gotyckich liter”. Ibidem, 53.

${ }^{22}$ Drahomíra Vlašinová, op. cit.

${ }^{23}$ „Boże słońce, które idziesz samotnie w ślepocie nadchodzącego czasu, idziesz do rozstajów w polu, gdzie się rozejdziemy, tam stoi krzyż”. Vladimír Körner, Adelheid, 53. 
- jasno świadcząc o fascynacji ojca Adelheid nazizmem i jego ideologią, jak również „wielkoniemiecką” przeszłością, symbolizowaną przez dzieła romantyków i filozofów, i mniej jednoznacznie wskazując na podobne możliwe fascynacje córki dawnego właściciela. Równocześnie zaś zawiera w sobie wskazówki, jak można odczytywać rozwój relacji pomiędzy bohaterami, komentarz autora do wydarzeń z czasów nie tylko przebiegu akcji, ale i pisania fabuły. Nie bez znaczenia pozostaje fakt, że właśnie lata sześćdziesiąte były momentem, w którym rozpoczęto starania, by na nowo odczytać wydarzenia wczesnego powojnia, takie jak wysiedlenia ludności niemieckojęzycznej, co znalazło swoje odbicie w dyskusjach historyków czechosłowackich, których zwieńczeniem był manifest Jana Mlynárika Tézy o vysídlení československých Nemcov z 1978 roku i następująca po nim fala artykułów, podająca tezy autora w wątpliwość lub zgadzająca się z nimi i dodająca nowe argumenty.

W takiej interpretacji biblioteka w Adelheid wpisuje się w stworzony przez Eco topos bibliotek ukrywających i pozwalających odnajdywać. Dzieje się tak na poziomie świata przedstawionego - gdzie ukrywa i odkrywa intencje, motywacje i przypuszczenia bohaterów, jak również na poziomie świata pozatekstowego - gdzie wskazuje na możliwe odczytania intencji i motywacji autora powieści. Odsłania to kolejne pokłady interpretacyjne, na których przydatność dla literaturoznawstwa zajmującego się odczytywaniem przestrzeni wskazywał dobitnie inny wielki pisarz, a zarazem teoretyk literatury, czyli Vladimir Nabokov w swoich Wykładach o literaturze. I chociaż, wzorem Nabokova, nie sporządziłam tutaj planu biblioteki, w której czas spędzają bohaterowie Körnera wierzę, że dowiodłam przedstawianych racji.

\section{ON THE MEANINGS OF LIBRARY IN ADELHEID BY VLADIMÍR KÖRNER. A CASE STUDY}

\section{Su m m a ry}

The author, starting with Umberto Eco's thesis on libraries that hide and allow to find meanings, analyses the meaning of library space and works it contains in the novel Adelheid by a Czech writer Vladimír Körner (1967). She assumes that they can be read both at the level of the textual world analysis and used to interpret the behaviour of the protagonists and their relationship, as well as at the non-textual level, as riddles hidden by the author for readers to solve. 